\title{
Vietnamese Students' Perception and Loyalty towards an Image of Vocational Education and Training
}

\author{
*Vi Hoang Dang1, 2, Tanya Hathaway² \\ ${ }^{1}$ Namdinh Vocational College - Vietnam \\ 2University of New England - Australia \\ *hdang2@myune.edu.au
}

\begin{abstract}
Stakeholders' perceptions towards a career in vocational education and training (VET) in Vietnam negate the country's industrial development plan. During the last 15 years, the Vietnamese Governments investment in to the sector increased annually. However, parents and their children still pursue the goal of higher education via the mainstream rather than a career path way using the vocational education and training system. Although stereotypical views of vocational students are being challenged, Confucian ideology maintains some influence over stakeholders' educational decisions leading to the sustained popularity of higher education. This study explores the perceptions of students on the image of and their loyalty towards vocational education and training. A sample of 300 lower secondary school, 300 upper secondary school, and 300 vocational students was drawn from across the Northern and Southern regions of Vietnam. A survey questionnaire was used to collect data and mean analysis conducted to explore the data. The findings indicate that agreement with statements about facilities and equipment, teacher's ability, curriculum, and soft skills are the clearest indicators of enhanced perceptions about the image of vocational education and training. Encouragement from parents appears most influential to positively affecting lower secondary students' loyalty. Unexpected was that vocational students had less interesting continuing in vocational education and training compared to lower and upper secondary school students inclination towards a career in VET. First-hand experience seemingly leads to diminished perceptions and loyalty towards vocational education.
\end{abstract}

Keywords: Vocational education and training, students, image, loyalty and perception

\section{Introduction}

Vocational education forms part of the vocational and technical education sector in Vietnam and runs parallel with the mainstream pathway to higher education via the school system (see Figure 1). Within the sector, Vocational Education and Training (VET) exist alongside Technical Education and Training (TET) and both are responsible for producing the skilled and technical workforce of the country. The VET system is under management of the General Directorate of Vocational Training (GDVT), which is one of the departments of the Ministry of Labour Invalid Social Affair (MOLISA). Its counterpart, the Ministry of Education and Training (MOET) manages the TET field. The main responsibility of the VET system is considered to be the production of a skilled workforce, not only in quantity of available workers, but also in quality of skills training required when implementing the government's Socio-Economic Development strategy in the period 2011-2020. In 2011,under the Vietnamese Prime Minister Nguyen (decision No. 630/QD-TTg, 2011), the Vocational Training Development Strategy (2011 - 2020) was implemented to increase the trained workforce by up to $40 \%$ (23.5 million people) by 2015 and up to 55\% (34.4 million people) by 2020. The Vietnamese government is therefore seeking to increase student enrolments in VET.

The establishment of a nationwide network of VET institutions demonstrates significant government effort to promote skilled education to Vietnam's future generation. Recent statistics (GDVT, 2011) show that the VET network has 1,293 registered providers including 136 vocational colleges, 308 vocational secondary schools and 849 vocational training centres. From 2006 to 2011, VET providers produced over 1,300,000 skilled workers with training lasting typically between 12 and 36 months (see Figure 1). In the period from 2006 to 2011, a further 7,000,000 workers were produced during short-term vocational training lasting between 3 and 12 months. According to GDVT (2011), over 80\% of students were successful in gaining employment immediately after graduation. In 2010, the GDVT (2011) reported that employment rates in the welding, automotive, and electrical divisions were approximately $90 \%$. The VET sector is made more attractive by its salaries. In the technical fields such as electricity, welding, computing, and mechanics vocational graduate were paid 10\% more than academic graduates. In addition, the ratio of students holding bachelor degrees, and even master's degrees that have been unable 
to secure employment and have therefore enrolled in vocational schools, is up by $30 \%($ Huy, 2014), Increasingly vocational education is seen as a means of acquiring the skills needed to gain employment with the realisation that the academic pathway may not be the best choice of career route in modern day Vietnam. In 2005, the National Assembly of Vietnam passed the new Education Law to recognize the VET system as a part of the national education system and establish its links with higher education. A significant outcome of this was the establishment of a route from VET to higher education (Figure 1).

Figure 1: The Vietnamese Educational System (Modified from London 2011)

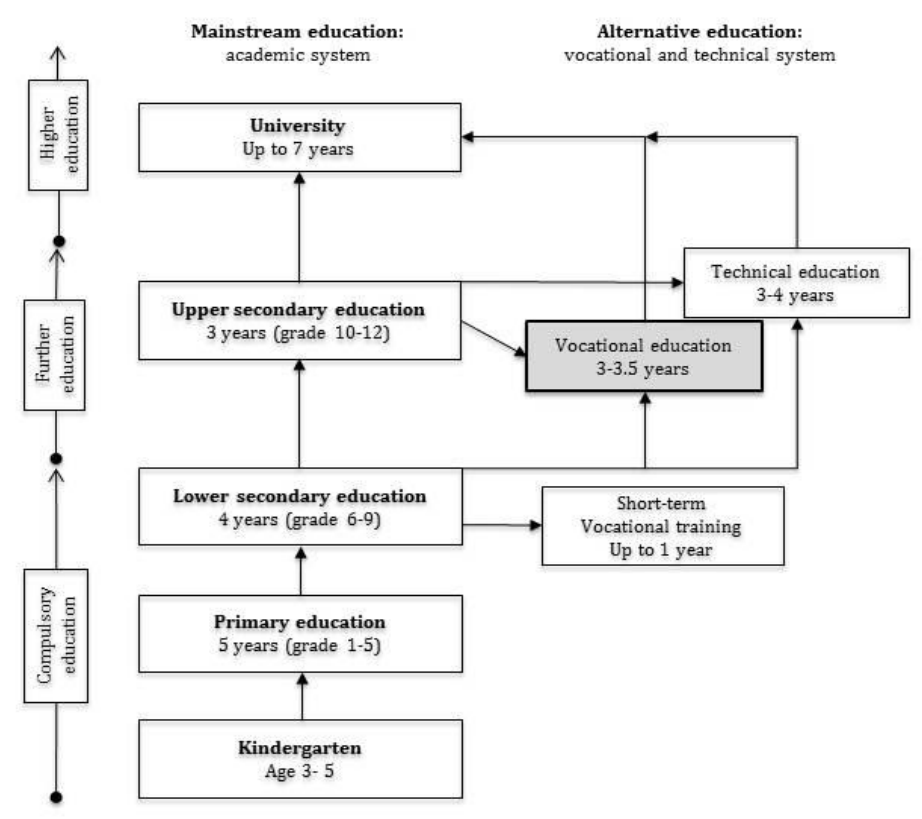

However, Confucian ideology still influences thinking in Vietnamese society and academic vocations are much more respected than others (London, 2011). Many consider vocational education an opt-out for delinquents; second class and blue collar workers, and so on. However, there are emergent signs of significant cultural and societal changes that may positively influence future attitudes towards and opinions of the VET system. Increasing engagement with globalization and internationalization are central to developing the country's economy. Since the introduction of the 'DoiMoi' or 'Open Door' policy in 1986, Vietnam has promoted itself as a friend to all other countries in the world.

Statement of the problem: Despite various efforts undertaken by the Vietnamese government to improve and expand VET in Vietnam (investment for VET increased ten-fold, from 49 million USD to 490 million USD in period from 2001 to 2011), the majority of students and parents still prefer mainstream education pathways to higher education and university rather than the technical and vocational education route. In the academic year 2010-2011, following graduation, $80.36 \%$ of lower secondary students continued into mainstream education and enrolled in high school compared to only $1.88 \%$ of lower secondary graduates who instead opted to enrol in vocational education and technical education schools (GDVT, 2011). For students graduating from upper secondary in the academic year 2011-2012, the statistics were equally damning, with $61.26 \%$ of students continuing to higher education level and only $10 \%$ continuing to technical and vocational education (MOET, 2013).Once students enter vocational education, evidence of disengagement with the experience is evident. According to the Vietnamese government (GDVT, 2011), a considerably high student dropout rate of $15 \%$ (equivalent to 21,782 students) was recorded at vocational secondary schools and vocational colleges in the academic year 2008-2011. This leads us to question whether students understand the vocational education system enough to appreciate the benefits of training and to question how this may influence their opinions about the quality and value of vocational education in Vietnam. 
This study explores the reasons for this lack of awareness and disengagement with VET from the perspective of the different student stakeholder groups - lower secondary school, upper secondary school and current vocational students. The purpose of this study is to investigate the perception of students on the image of VET with the interest to understand their influence on student's loyalty to the image of vocational education and training, and motivation to remain in training programmes once enrolled. This study aims to answer the following research questions:

- What are lower and upper secondary school students, and current vocational students' perception of the image of VET?

- What is the extent of students' loyalty towards the VET sector?

- Where do students' loyalties towards the VET sector originate?

Wider significance of the study: Aside from the main student stakeholders, the findings from this study have a wider significance to groups of associated stakeholders such as parents, industry, VET policy makers and young people who have an overview of the VET sector in Vietnam. The findings from this study will provide solid and reliable evidence of students' perception and evaluation of the sector. They may also assist policy makers in planning future programs related to changing cultural attitudes towards VET, at the level of schools, communities and government. Furthermore, the findings will inform the decision making of student stakeholders with regard to future study in either vocational education and training or mainstream education. It has the potential to impact the employability and career choices of Vietnam's younger generation.

\section{Literature review}

Perceptions towards the VET sector in Vietnam: Perception is the process of receiving information about and making sense of the world around us. It involves deciding what to notice, how to categorize it and how to interpret it within the framework of existing knowledge (Steven \& Mary, 2003). Perception plays an important role in guiding and predicting future actions. Our perceptions are filtered and current experiences interpreted according to prior experience and the values and beliefs that represent our cultural norms. For the purpose of this study, we conceptualize perception as the feeling or thinking stakeholders have towards the VET sector, particularly their attitudes, influences and preconceptions about attending VET programs. In order to understand the perception of Vietnamese stakeholders and cultural views of education we must explore the ideology and influence of Confucianism. Broadly, the Confucian philosophy relates to education for morality and the achievement of social ordering, and the establishment of social stability. Education is seen as the pathway to a better life. While, Confucianism assumes differences in intelligence, education is seen as the primary influence on morality. Academic education is thus respected and seen as preferable because it instils the morals and virtues that reinforce the social rules and regulation. The abandonment of vocational education is an outcome of this ideology. The emerging message from the state in support of VET seems undermined in Vietnam, as Confucian ideology wrestles with the state for power and control over education choice.

In spite of this, positive views of the VET exist. At the macro level, positive proponents of VET perceive it as significant to reducing the rate of unemployment and meeting the needs of industries (Euro barometer, 2011). Some clearly see VET as being a valuable part of the national framework of education. They contend that participation in vocational education appears to contribute to the development of greater self-confidence in students, an improved ability to work and get along with others, a clear sense of career direction and greater feelings of success and belonging. From a negative perspective, others perceive VET as a second rate education and an easy way to discriminate between students based on academic ability (Awang, Sail, Alavi \& Ismail, 2011); this perception is compounded by a lack of progression routes from VET into higher education (GDVT, 2011). The VET sector is viewed across Vietnam as a sinkhole for those who are not able to function within the academic environment. Skilled workers are associated with the working class whose remit is to serve and submit to management from middle class academics. The negative proponents argue that VET inhibits opportunities for the disadvantaged or academically alienated to participate more fully in society by fostering compliant work attitudes and an acceptance of low status employment or no employment (Cohen \& Besharov, 2002).

At an individual level, Awang, et al. (2011) considers the image of vocational education and training as '...one of the key factors that play an influential role in students' decisions to enrol in these programs'. Papalia \& Sally (1985) contend that perception is an overall learned core disposition that guides a person's thoughts, feelings, and actions towards an object. Students' perceptions of VET are formed in the 
social context and different groups can influence the decisions students make about the value of VET. As adolescents, students are still learning about themselves and the world and are therefore readily open to influence from others. In Vietnam, parental views have strong potential to influence students' decision to remain in mainstream education rather than explore the benefits of alternative education and a career in the vocational system. The choice to remain in mainstream education is taken when students are in secondary school. Whilst having only simple knowledge of the VET sector, teachers and school counsellors are in a primary position to influence students' decisions. Indeed, many teachers only experience of vocational or technical education is through reading marketing literature distributed to schools.

Changing the public perceptions towards the VET sector is vital. Nguyen (2014) suggests that perceptions can be improved by: government promotion of VET as an alternative educational route for school leavers; media promotion of the role of VET in wealth creation; the provision of 'awareness weeks', exhibitions and open days by VET institutions; and improved salaries for VET graduates. He also recommends a sustained campaign by policy makers, educationalists, civil society groups and other interested parties to alter perceptions, suggesting that this can 'be done, in part, by promoting the positive features of "alternative" training pathways, explaining how the specificities of local economic and [labour] demands are met through training workers; demand is met by supply'. Associating VET with modern science and technology rather than manual labour is also critical to improving perceptions. Furthermore, Nguyen (2014) suggests that finding ways to facilitate co-operation between industries and VET institutions to improve employment outcomes or quality of human resources would be one important approach to shifting perceptions.

Constructing an image of VET: One approach to constructing a measureable image of VET is to attempt to quantify its constructs or dimensions. Hadikoemoro (2002) contends that the image of vocational education and training is comprised of many dimensions making it unfeasible to produce an accurate description. However, Dagger et al. (2007) are less hesitant and suggest that the image of an organization or service quality is a multidimensional and hierarchical construct. Either way, developing a framework that accurately depicts an image of VET and can measure student's perception is a very complex and tedious task. According to Gronroos (1984), a relationship exists between university image and student's perception. His findings indicate that university image and service quality are drivers (antecedents) for students' perception. In the same vein, students' satisfactions with service quality and university image are mediating variables that can be considered to form part of students' perception. Consequently, students' satisfaction with the service that is provided by the university is assumed to have a positive association with the image of the university (Helgesen \& Nesset, 2011). Because university image has been shown to impact students' perceptions, thus a favourable and well-known university image is an asset for the education provider (Gronroos, 2001). Similarly, Rossetti's (1990) research found that the relationship between the image of vocational education and number of students enrolled in VET was proportional, meaning that a negative image leads to a decrease in the number of students enrolling in VET.

Awang et al. (2011) used a model of the image of VET consisting of seven dimensions to measure what high school students and current vocational students perceived, thought or felt about VET in Malaysia. The dimensions were: low entry qualification, trainers' credibility, applicability of course contents, training facilities and equipment, recognition of qualification, future career potential, and work ethics and social values. Their findings demonstrated that the dimensions of recognition of qualification, work ethics, social values, and applicability of course content all impact majorly on students' perceptions towards the VET field. In the only major study of the VET system in Vietnam, the GDVT (2011)summarized 12 main dimensions that quantify and describe an image of VET showing "...a picture with multiple colours on vocational training in Vietnam and also not merely the picture for 2011 but also that of the actual vocational training status in Vietnam at present stage".

Students' loyalty towards VET: In order to define students' loyalty, literature from the field of marketing provides a conceptual basis and one way of thinking about loyalty. A loyal customer is defined as one who would continue to purchase goods or service from the same company whenever possible, and who continues to maintain positive perceptions towards goods and services from the company (Reichheld \& Sasser, 1990). According to Oliver (1999), if situational influences and marketing efforts are ignored, customer loyalty is defined as a self-promise to repurchase or re-choose a preferred product or service, this action, which will continue in the future, causing repetitive same brand or same brand series 
purchasing. Two main behavioural and attitudinal dimensions form a customer's loyalty (HenningThurau et al., 2001). The behaviour dimension refers to a customer's behaviour in respect of repeat purchases, indicating a preference to a brand or service over time (Reichheld \& Sasser, 1990); loyalty, in the behavioural sense, is then measured by using repurchase probability, long-term choice probability, or switching behaviour. The attitudinal dimension, on the other hand, refers to a customer's intention to repurchase and make recommendations, and is considered a good indicator of a loyal customer (Getty \& Thompson, 1994). Kumar \&Shah (2004) note that attitudinal loyalty has been often defined in the context of brand as it captures the affective and cognitive aspects of brand loyalty, such as brand preference and commitment (Mellens, Dekimpe, \& Steenkampe, 1996). Moreover, a customer who intends to repurchase and recommend is more likely to remain loyal to the company. Based on Yu \&Alison's (2001) study, there are four aspects to measuring customer loyalty.

- Word of mouth: this positive communication can be in form of recommending to friends, expressing positive comments about the product and encouraging others to use the product

- Complaint behaviour: demonstrated when complaining to an employee or supervisor about a problem that arises when using the product.

- Switching behaviour: this is shown by the effort to switch to other company's product, tempted by other company's offer and accepting other company's offer.

- Willingness to pay more: this aspect is related to consumer willingness to keep on buying and paying for the product although there is an increase in the product's price.

In translating the definition of customer's loyalty to students' loyalty towards the VET sector, the meaning in this study was slightly different depending on the stakeholder subgroup. For those currently studying with vocational education training providers, loyalty was defined as the intention to continue with their studies. For students in secondary schools, loyalty was defined as demonstrating positive thinking towards the VET sector.

\section{Methodology}

This study uses a survey questionnaire to collect data and to determine the students' perception towards the image of VET, and loyalty towards the sector.

Sample and procedure: The participants in the study were consenting students from lower secondary school (year 9), upper secondary school (year 12) and students currently enrolled in vocational education and training programs across both the Northern and Southern regions of Vietnam. The questionnaire surveys were distributed by the lead research during visits made to participating institutions in February 2014, marking the end of the 2013-2014academic year. Participant selection was on the basis of students' eligibility to enter VET or current enrolment. Using a survey questionnaire, participants were asked to evaluate the image of VET and their perceptions of VET as a viable route to higher education and employment. Participants were sourced from an area representative of the wider Vietnamese population. Three provinces were purposively selected from each region based on the researchers' knowledge of the area. In the northern region these were Nam Dinh, NinhBinh and Hai Duong provinces. In the south these were the BinhPhuoc, Dong Nai, Vung Tau provinces. Each provincial data collection point was located approximately $100 \mathrm{~km}$ from its neighbouring data collection point situated in another province. In each province, six schools (two lower secondary, two upper secondary and two vocational) were then randomly selected and approached to participate in the study. Adopting a systematic approach to selection, 25 students in each school were chosen from the relevant year in the student book list. Starting with student number one, then number four, number seven and so on counting three students each time. Students were then formally invited to participate in the survey and asked for their written consent. In total, six schools were surveyed in each province, gathering a total of 150 completed surveys per province. In total, 450 participants were recruited from both the Northern and Southern regions providing900 data points.

Instrumentation: The measurement of VET's image (independent variable) and student's perception and loyalty (dependant variable) was based on a modified version of the image of vocational education scale used by Awang et al. (2011) in their study of Malaysian students' loyalty towards technical and vocational education and training. The original scale was itself based on instruments that have been used in past studies adapted and blended with previous research (see Awang et al. 2011 for full details). Direct application of a scale developed in one culture to another can lead to issues of validity and reliability, the 
version of the scale used in this study was therefore further adapted and blended with research appropriate to the vocational education and training sector (Awang et al., 2011; Parasuraman et al., 1994) and the Vietnamese context (GDVT, 2011).The only major study (GDVT, 2011) in this area identified twelve main dimensions that quantify and describe the VET system in Vietnam. These were used to provide culture specific points of reference that could be blended into the modified scale. In the final scale, seven dimensions explained the image of VET and measured student's perceptions, these are: entry requirement, facility and equipment, teacher's ability, recognition of qualification, student career and job potential, curriculum, and soft skills. The accompanying measure of student loyalty devised by Awang et al. (2011) was similarly modified for use in the Vietnamese context and culture. Four subjective measures of students' loyalty towards the VET sector were considered by asking students' intentions on: further study, field of interest, career choice and parental encouragement. A questionnaire was devised utilising a five-point Likert scale measuring the image of VET and student's perception and loyalty towards VET based on responses to five categories $(1=$ strongly disagree; $2=$ disagree; $3=$ neutral; $4=$ agree; $5=$ strongly agree). Participants were asked to provide the most appropriate answer to a set of 64 statements. The seven dimensions making up the image of VET (independent variable) were measured using 45 questions that asked students' evaluation based on their experience and knowledge of the sector. The four dimensions measuring students' loyalty (dependent variable) were measured using 19 questions asking their intentions towards the VET sector.

\section{Data analysis}

The quantitative data, consisting of 900 student responses to 64 statements contained in the survey questionnaire, were coded and entered into the Statistical Package for the Social Sciences (SPSS) version 19 for analysis. A means analysis technique was applied to determine what lower and upper secondary school students, and current vocational students thought, evaluated or perceived about the image of VET and loyalty towards VET. The mean score from $1.00-1.80$ was strongly disagree, $1.81-2.60$ disagree, $2.61-3.40$ neutral, $3.41-4.20$ agree and $4.21-5.00$ strongly agree.

Students' perceptions towards VET: Table 1 describes the mean scores of the first dimension of VET image, entry requirement. All student groups recognised that VET is accessible to all secondary school students graduating from year nine onwards. On the other hand, all three groups disagreed, some more strongly than others, that vocational education training students have low academic grades and that the VET sector is wholly for disabled students, juvenile delinquents and problematic students.

Table 1: Entry requirement

\begin{tabular}{llll}
\hline mension: Entry requirement & $\begin{array}{c}\text { Mean } \\
\text { Year 9 } \\
\text { students }\end{array}$ & $\begin{array}{c}\text { Mean } \\
\text { Year 12 } \\
\text { students }\end{array}$ & $\begin{array}{c}\text { Mean } \\
\text { Vocational } \\
\text { students }\end{array}$ \\
\hline 14) All year 9 students who have graduated onwards can enter VET & 4.05 & 3.83 & 3.90 \\
15) Vocational students are low academic achievers & 2.03 & 2.01 & 2.12 \\
16) Vocational students have disabilities & 1.80 & 1.79 & 1.93 \\
17) Requirements to enter VET are low and flexible & 2.72 & 2.78 & 2.81 \\
18) Vocational students are juvenile delinquents and problematic & 1.70 & 1.64 & 1.93 \\
19) VET is for people who not aspire to a higher level of education & 2.71 & 2.31 & 2.46 \\
\hline
\end{tabular}

Overall, students expressed positive perceptions in the facility and equipment dimension as shown in Table 2. This may be the result of recent financial investment in VET institutions. The dimension measures perceptions about the efficacy of VET teaching and learning, and recreational facilities to supporting quality education including students' social outcomes.

Table 2: Facilities and equipment

\begin{tabular}{llll}
\hline mension: Facilities and equipment & Mean & Mean & Mean \\
& $\begin{array}{c}\text { Year 9 } \\
\text { students }\end{array}$ & $\begin{array}{c}\text { Year 12 } \\
\text { students }\end{array}$ & $\begin{array}{c}\text { Vocational } \\
\text { students }\end{array}$ \\
\hline 20) The laboratory/workshop is suitable for teaching and learning & 3.83 & 3.69 & 3.5 \\
\hline
\end{tabular}




\begin{tabular}{llll}
\hline 21) The laboratory/workshop is advanced & 3.43 & 3.5 & 3.25 \\
22) Equipment is fit for purpose and the latest technology & 3.4 & 3.53 & 3.31 \\
23) The classes have sufficient space to support quality education & 3.83 & 3.84 & 3.61 \\
24) VET providers offer sports and recreational facilities & 3.86 & 3.85 & 3.45 \\
\hline
\end{tabular}

Table 3 indicates that secondary school students were more positive about the ability of VET teachers than current vocational students. While current vocational students were in agreement, they were less enthusiastic perhaps reflecting their concrete experiences of VET teachers.

Table 3: Teacher's ability

\begin{tabular}{lccc}
\hline Dimension: Teacher's ability & $\begin{array}{c}\text { Mean } \\
\text { Year 9 } \\
\text { students }\end{array}$ & $\begin{array}{c}\text { Mean } \\
\text { Year 12 } \\
\text { students }\end{array}$ & $\begin{array}{c}\text { Mean } \\
\text { Vocational } \\
\text { students }\end{array}$ \\
\hline 25) Vocational teachers/instructors are helpful & 4.28 & 3.81 \\
26) Vocational teachers/instructors are experienced & 4.36 & 4.07 & 3.93 \\
27) Vocational teachers/instructors are highly qualified & 3.99 & 4.06 & 3.93 \\
\hline
\end{tabular}

All students had less favourable perceptions about the credence of a qualification gained from VET in terms of recognition by foreign and private companies, and overseas higher education institutions (see Table 4). Conversely, students had more positive perceptions about the adequacy of a VET qualification to influencing their ability a gain suitable employment. Overall though, they were in agreement that a degree gained in the higher education sector was of a higher status than a vocational degree.

Table 4: Recognition of vocational qualification

\begin{tabular}{|c|c|c|c|}
\hline Dimension: Recognition of vocational qualification & $\begin{array}{l}\text { Mean } \\
\text { Year } 9 \\
\text { students }\end{array}$ & $\begin{array}{l}\text { Mean } \\
\text { Year } 12 \\
\text { students }\end{array}$ & $\begin{array}{l}\text { Mean } \\
\text { Vocationa } \\
\text { l students }\end{array}$ \\
\hline $\begin{array}{l}\text { 28) A vocational qualification provides opportunities for further } \\
\text { education }\end{array}$ & 3.66 & 3.71 & 3.67 \\
\hline 29) A vocational qualification makes it is easier to find a suitable job & 3.6 & 3.73 & 3.67 \\
\hline 30) A vocational qualification is recognized by foreign companies & 3.04 & 3.28 & 3.24 \\
\hline 31) A vocational qualification is recognized by private companies & 3.14 & 3.2 & 3.39 \\
\hline 32) A vocational qualification is recognized by universities in Vietnam & 3.51 & 3.42 & 3.3 \\
\hline 33)A vocational qualification is recognized by overseas higher education & 3.15 & 3.17 & 3.02 \\
\hline 34) Higher education degrees are more valuable than vocational degrees & 3.68 & 3.43 & 3.32 \\
\hline
\end{tabular}

Table 5: Student career and job potential

\begin{tabular}{lllc}
\hline Dimension: Student career and job potential & $\begin{array}{c}\text { Mean } \\
\text { Year 9 } \\
\text { students }\end{array}$ & $\begin{array}{c}\text { Mean } \\
\text { Year 12 } \\
\text { students }\end{array}$ & $\begin{array}{c}\text { Mean } \\
\text { Vocational } \\
\text { students }\end{array}$ \\
\hline 35) Produces highly skilled trainees & 3.46 & 3.64 & 3.36 \\
36) Produces trainees with a wide range of job opportunities & 3.63 & 3.68 & 3.63 \\
37) Work is at a high level of risk & 2.28 & 2.51 & 2.62 \\
38) Gain adequate welfare payment & 3.38 & 3.42 & 3.51 \\
39) Provide professional growth opportunities & 3.69 & 3.8 & 3.67 \\
40) Meet the national industrial workforce needs & 3.66 & 3.73 & 3.68 \\
41) Gain a job immediately after graduation & 3.4 & 3.55 & 3.51 \\
\hline
\end{tabular}


In general, students had positive perceptions about the future availability of job opportunities and professional growth opportunities for VET graduates in the workforce (Table 5). This was reflected in their disagreement that employment in the VET sector was a high risk venture suggesting they perceived employment in VET as having a secure future. In terms of national industrial workforce needs, students perceived VET offered a positive contribution. Table 6 indicates that, in general, all student groups had positive perceptions of the robustness of the VET curriculum. Interestingly, whilst the mean responses to item 46 demonstrated that students were ambivalent to the level of challenge offered by the VET curriculum, they perceived it offered a course tailored to low academic achievers.

Table 6: Curriculum

\begin{tabular}{|c|c|c|c|}
\hline Dimension: Curriculum & $\begin{array}{c}\text { Mean } \\
\text { Year } 9 \\
\text { students }\end{array}$ & $\begin{array}{l}\text { Mean } \\
\text { Year } 12 \\
\text { students }\end{array}$ & $\begin{array}{c}\text { Mean } \\
\text { Vocational } \\
\text { students }\end{array}$ \\
\hline 42) Provide an integration of academia and skills & 4.07 & 3.8 & 3.64 \\
\hline 43) Provide for a very specific career field & 4.01 & 3.79 & 3.75 \\
\hline $\begin{array}{l}\text { 44) Provide a foundation for trainees who are planning to attend } \\
\text { further study }\end{array}$ & 3.88 & 3.9 & 3.74 \\
\hline 45) Many of the course options offered are very interesting & 3.98 & 3.72 & 3.38 \\
\hline 46) A hands-on simple education and training & 2.54 & 2.92 & 2.99 \\
\hline $\begin{array}{l}\text { 47) Have an excellent remedial program for academically low } \\
\text { achieving trainees/students }\end{array}$ & 3.70 & 3.64 & 3.51 \\
\hline $\begin{array}{l}\text { 48) Have good connections between vocational school and } \\
\text { industries }\end{array}$ & 3.77 & 3.71 & 3.49 \\
\hline 49) Have good connections with community & 3.92 & 3.71 & 3.63 \\
\hline
\end{tabular}

Overall, students agreed with almost all of the items in the dimension of soft skills (see Table 7). They perceived that students graduating from the VET sector are able to make a valuable contribution as key co-workers. In contrast, it appears that graduating from VET is not linked with the ability to be selfdirected as demonstrated by being able to work independently, demonstrate leadership and communication skills students where student responses were neutral. This suggests that career training through VET is not seen as providing the skills to promote noticeable individuals the field of employment.

Table 7: Soft skills

\begin{tabular}{llll}
\hline Dimension: Soft skills & $\begin{array}{c}\text { Mean } \\
\text { Year 9 } \\
\text { students }\end{array}$ & $\begin{array}{c}\text { Mean } \\
\text { Year 12 } \\
\text { students }\end{array}$ & $\begin{array}{c}\text { Mean } \\
\text { Vocational } \\
\text { students }\end{array}$ \\
\hline 50) VET graduates have responsibility for their work & 3.68 & 3.75 & 3.73 \\
$\begin{array}{l}\text { 51) VET graduates work independently } \\
\text { 52) VET graduates are valuable citizens in society }\end{array}$ & 3.06 & 3.25 & 3.21 \\
53) VET graduates are creative and innovative & 3.63 & 3.74 & 3.7 \\
54) VET graduates have teamwork skills & 3.59 & 3.67 & 3.73 \\
55) VET graduates have self-discipline & 3.68 & 3.71 & 3.78 \\
56) VET graduates have information and communication & 3.65 & 3.46 & 3.43 \\
technology skills & 3.58 & 3.58 \\
57) VET graduates have leadership skills & 3.11 & 3.19 & 3.26 \\
58) VET graduates have communication skills & 3.21 & 3.38 & 3.5 \\
\hline
\end{tabular}

Summary: In general, lower and upper secondary school and current vocational students had a positive evaluation or perception towards the image of VET (Chart 1 and Table 8). The responses from upper secondary students were positive in all dimensions, with the exception of entry requirement. All groups had a neutral perception or disagreed, sometimes strongly, with respect to VET students having low 
academic grades, being disabled, demonstrating juvenile delinquency and being problematic. These indicate that stakeholders are able to see beyond the stereotypical images of VET students and the implications for vocational education, to more accurately perceive that VET is not an easy option undertaken by students demonstrating negative social traits. Overall, the mean scores depicted in Table 8 reveal that lower secondary students were the most positive about VET teacher's ability, perhaps reflecting untainted beliefs about VET and an idealised image. Whilst positive, current VET students' perceptions of their teachers' ability were lower, perhaps reflecting their first-hand experiences of the VET sector.

\section{Chart 1: Mean scores of independent variables}

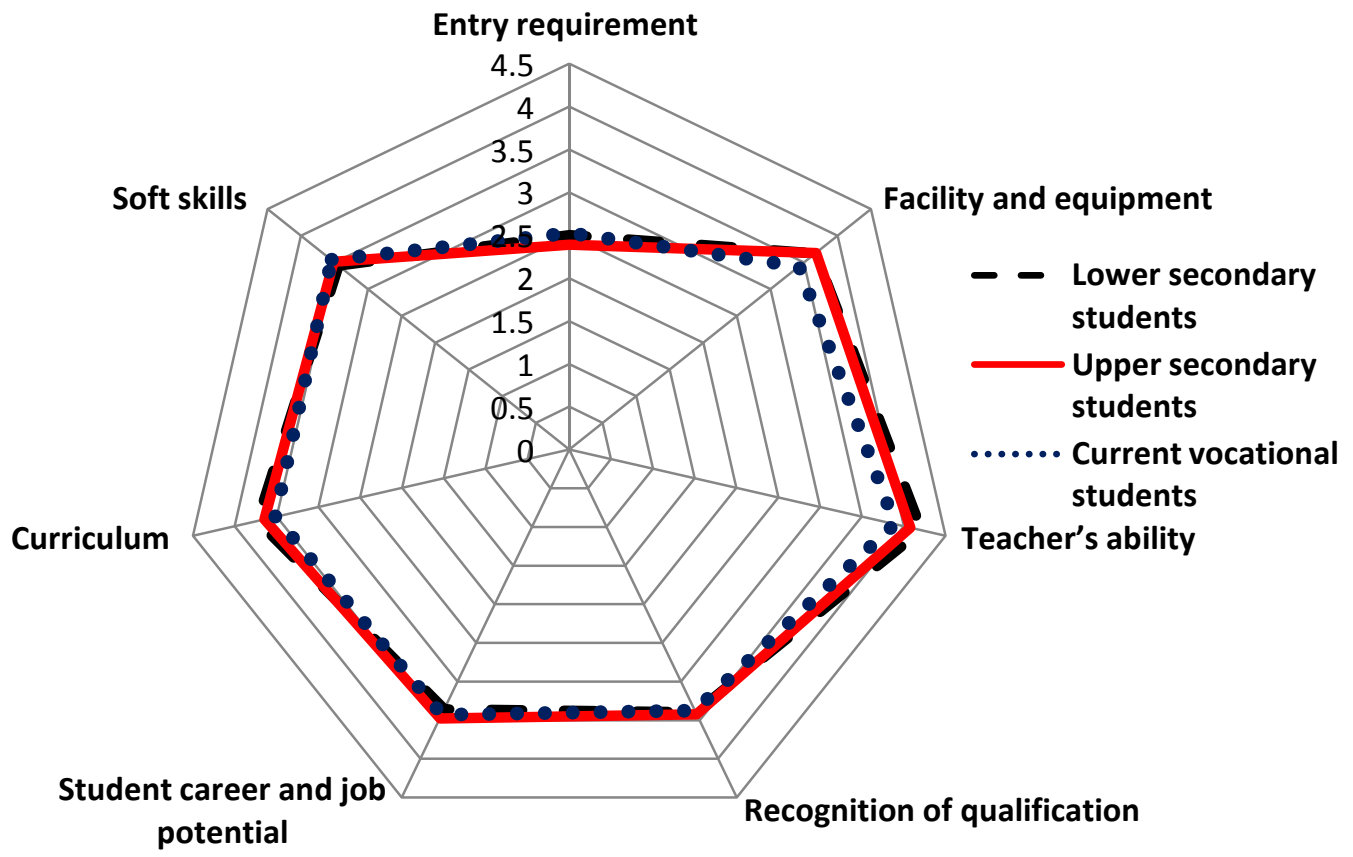

Table 8: Mean scores of dimensions

\begin{tabular}{llllllll}
\hline Student & $\begin{array}{l}\text { Entry } \\
\text { requirement }\end{array}$ & $\begin{array}{l}\text { Facility } \\
\text { and } \\
\text { equipment }\end{array}$ & $\begin{array}{l}\text { Teacher's } \\
\text { ability }\end{array}$ & $\begin{array}{l}\text { Recognition } \\
\text { of } \\
\text { qualification }\end{array}$ & $\begin{array}{l}\text { Student } \\
\text { career and } \\
\text { job } \\
\text { potential }\end{array}$ & Curriculum & $\begin{array}{l}\text { Soft } \\
\text { skills }\end{array}$ \\
\hline Lower & 2.5017 & 3.6700 & 4.2100 & 3.3957 & 3.3571 & 3.7333 & 3.4426 \\
Upper & 2.3922 & 3.6813 & 4.0778 & 3.4224 & 3.4762 & 3.6479 & 3.5163 \\
Vocational & 2.5256 & 3.4253 & 3.8911 & 3.3729 & 3.4276 & 3.5179 & 3.5485 \\
\hline
\end{tabular}

Students' loyalty towards VET: The total score for students' loyalty towards the VET sector was obtained from the summation of responses based on the four item statements shown in Table 9. A lower mean score indicates a lower level of students' loyalty and inversely, a higher mean score indicates a higher level of students' loyalty. The items with the highest means of students' loyalty, expressed as agreed, were parental encouragement $(M=3.70 ; M=3.59$, and $M=3.56)$, further study $(M=3.50, M=3.50$, and $M=3.60)$ and career choice $(M=3.48, M=3.49$ and $M=3.38)$ with the exception of vocational students. However, Table 9 shows field of interest had slightly low mean scores ( $M=3.04, M=3.12$ and $M=3.09)$ indicating an overall neutral response. In conclusion, students almost universally demonstrated loyalty towards VET although it was not necessarily their primary field of interest. 
Table 9: Student's loyalty towards the VET sector

\begin{tabular}{|c|c|c|c|}
\hline \multirow{2}{*}{ Item } & Mean & Mean & Mean \\
\hline & Year 9 students & Year 12 students & Vocational students \\
\hline Further study & 3.5089 & 3.5011 & 3.6056 \\
\hline Career choice & 3.4833 & 3.4980 & 3.3873 \\
\hline Field of interest & 3.0492 & 3.1279 & 3.0996 \\
\hline Parental encouragement & 3.7067 & 3.5900 & 3.5644 \\
\hline
\end{tabular}

\section{Conclusion and Implications}

This study sought to examine what student stakeholders perceive with respect to the image of VET and their engagement with the concept. The findings and discussions above lead to the conclusion that in general stakeholders have positive perceptions and loyalty towards the image of VET. The dimensions of facility and equipment, teacher's ability, curriculum, and soft skills were considered the clearest indicators of students' agreement with the image of VET, although current vocational students' perception was less optimistic in these areas. Overall, lower and secondary school students tend to have enhanced perception of the image of VET compared to current vocational students, with the exception of the dimension soft skills. It seems that first-hand experience of VET lowers individual agreement with its positive features. In terms of students' loyalty and future intentions to the VET sector, parental encouragement and opportunities for further study were experienced most strongly. Support and advice from parents appear to be a critical feature of lower secondary students' loyalty and key to improving efforts to attract young people into the VET sector, although over time, and with increasing student age, this influence may decrease. The findings suggest that students are more likely to pursue VET if clear linkage between the sector and the higher education system is visible, as required in the 2005 Education Law. As with the image of VET, current vocational students demonstrated less loyalty than lower and upper secondary students. It appears that first-hand experience of VET leads to diminished perceptions and reduced loyalty. These findings have important implications for the promotion of VET to young people. Quality of facilities and equipment, teacher's ability, curriculum, and soft skills should be promoted widely through the media such as radio, television, internet, and conferences. Furthermore, dissemination of information to students, parents and other stakeholders, by exhibition should be organized annually from the district to state level to promote VET more widely, and to attract and encourage secondary school students to enrol in VET. Early promotion of the VET sector to students while still at school may be more effective if parents are included.

Public perceptions of the VET sector can be altered by informed publicity highlighting the career success of the skilled workforce via documentary films or television. As young people and students are more influenced by the opinions of others around them, stories depicting successful skilled workers may have greater impact if brought directly into school classrooms. It is therefore vital that schools and careers services offer timely, good quality information and advice about VET. With industry's increasing demands for skilled workers, the GDVT should seize this moment of opportunity to disseminate information in a bid to attract more youths to enrol in VET. Finally, the continued influence of Confucian ideology in Vietnam should not be ignored or underestimated. The principle doctrine of the Confucian philosophy is to train the perfect people to serve for government and lead other people. University education is central to this belief. As the results reveal here, whilst students are generally positive towards VET, mainstream education persists as the primary route for students to higher education. However, the future is optimistic. The findings from this study reveal that the widespread perception that students who undertake vocational education are academically weak and disruptive is now being challenged. In addition, the influence of the 'open door' policy and the dimensions of internationalization and globalization, means that these perceptions are finally beginning to shift.

Acknowledgement: The authors wish to acknowledge earlier discussions about the project with Brian Denman that made invaluable contributions to our thinking. 


\section{References}

Awang, A. H., Sail, R. M., Alavi, K. \& Ismail, I. A. (2011). Image and students' loyalty towards technical and vocational education and training. Journal of Technical Education and Training, 3(1), 13-28.

Child, D. (1990). The essentials of factor analysis. London: Cassel Educational Limited.

Cohen, M. \& Besharov, D. (2002). The role of career and technical education: implications for the federal government. US Department of Education, Office of Vocational and Adult Education, Washington.

Dagger, T. S., Sweeney, J. C. \& Johnson, L. W. (2007). A hierarchical model of health service quality: Scale development and investigation of an integrated model. Journal of Service Research, 10(2), 123142.

Eurobarometer, L. (2011). Attitudes towards vocational education and training. Retrieved fromec.europa.eu/public_opinion/archives/ebs/ebs_369_en.pdf

General Directorate of Vocational Training (GDVT). (2011). Báocáodạnghề 2011. Retrieved fromhttp://www.slideshare.net/tinhanhvy/bo-co-dy-ngh-vit-nam-2011

Getty, J. M. \& Thompson, K. N. (1994). The relationship between quality, satisfaction, and recommending behaviour in lodging decision. Journal of Hospitality \&Leisure Marketing, 2(3), 3-22.

Gronroos, C. (1984). A service quality model and its marketing implications. European Journal of Marketing, 18(4), 36-44.

Gronroos, C. (2001). The perceived service quality concept-a mistake? Managing Service Quality, 11(3), 150-152.

Hadikoemoro, S. (2002).A comparison of public and private university students' expectations and perceptions of service quality in Jakarta, Indonesia. (Unpublished PhD thesis).Nova South eastern University.

Helgesen, 0. \& Nesset, E. (2011). Does LibQUAL+TM account for student loyalty to a university college library? Quality Assurance in Education, 19(4), 413-440.

Henning-Thurau, T., Lager, M. F. \& Hansen, U. (2001). Modelling and managing student loyalty: An approach based on the concept of relationship quality. Journal of Service Research, 3(1), 331-344.

Huy, L. (2014). Thạcsĩ, cưnhân ồ ạthọctrungcấp. Retrieved from http://truongtrungcapnghehatinh.edu.vn/thac-si-cu-nhan-o-hoc-trung-cap

Kumar, V. \& Shah, D. (2004). Building and sustaining profitable customer loyalty for the 21st century. Journal of Retailing, 80(4), 317-330.

London, J. D. (2011). Education in Vietnam: Historical Roots, Recent Trends. In J.D. London (Ed.), Education in Vietnam. Singapore: Institute of Southeast Asian Studies Press.

Mellens, M., Dekimpe, M. G. \& Steenkamp, J. B. E. M. (1996). A review of brand loyalty measures in marketing. Tijdschri ftvoorEconomieen Management, 41(4), 507-533.

Ministry of Education and Training (MOET). 2013. Thốngkếgiáodụcnăm 2013. Retrieved from http://www.moet.gov.vn/?page=11.11\&view=5251

Nguyen, N. P. (2014). Cơcấulạihệthốngdạynghề. Retrieved from http://www.baomoi.com/Co-cau-lai-he thong-day-nghe/59/14459397.epi

Oliver, R. L. (1999). Whence consumer loyalty? Journal of Marketing, 63, 33-44.

Papalia, D. E. \& Sally, D. (1985). Psychology. New York: McGraw-Hill Book Company.

Parasuraman, A., Zeithml, V. \& Berry, L. L. (1994). Reassessment of expectation as a comparison standard in measuring quality implications for further research. Journal of Marketing, 58(1), 111-124.

Reichheld, F. F. \& Sasser, W. E. (1990). Zero defections: Quality comes to services. Harvard Business Review, 68(5), 105-111.

Rossetti, R. (1990). An examination of factors influencing students not to enrol in secondary vocational education. Columbus, OH: Ohio State University, Department of Agricultural Education.

Steven, L. M. C. \& Mary, A. Y. V. G. (2003). Organizational behaviour. Toronto: McGraw-Hill Ryerson.

Yu, Y. T. D. \& Alison, D. (2001). The contribution of emotional satisfaction to consumer loyalty. International Journal of Service Industry Management, 12(3), 234-250. 